\title{
A Phylogenetic Analysis of Borrelia burgdorferi Sensu Lato Based on Sequence Information from the $h b b$ Gene, Coding for a Histone-Like Protein
}

\author{
CLAUDIO VALSANGIACOMO, ${ }^{*}$ TIZIANO BALMELLI, AND JEAN-CLAUDE PIFFARETTI \\ Istituto Cantonale Batteriosierologico, CH-6904 Lugano, Switzerland
}

\begin{abstract}
We describe a phylogenetic investigation of Borrelia burgdorferi sensu lato, the causative agent of Lyme disease, based on a DNA sequence analysis of the $h b b$ gene, which encodes protein $\mathrm{HBb}$, a member of the family of histone-like proteins. Because of their intimate contact with the DNA molecule, these proteins are believed to be fairly conserved through evolution. In this study we proved that the $h b b$ gene is suitable for phylogenetic inference in the genus Borrelia. The $h b b$ gene, which is $327 \mathrm{bp}$ long and encodes 108 amino acids, was sequenced for 39 strains, including 37 strains of $B$. burgdorferi sensu lato, 1 strain of Borrelia turicatae, and 1 strain of Borrelia parkeri. Genetic variability was determined at the sequence level by computational analysis. Briefly, 81 substitutions were scored at the DNA level. Only 25 of these substitutions were responsible for amino acid substitutions at the translational level. The signature region for bacterial histone-like proteins was found in $h b b$. Although variable at the nucleotide level, it was highly conserved at the deduced amino acid level. A phylogenetic tree for the genus Borrelia that was generated from multiple sequence alignments was consistent with previously published data derived from DNA-DNA hybridization and multilocus enzyme electrophoresis analyses. The subdivision of $B$. burgdorferi sensu lato into five species (B. burgdorferi sensu stricto, Borrelia garinii, Borrelia afzelii, Borrelia japonica, and "Borrelia andersonii") and at least four genomic groups (groups PotiB2, VS116, CA2, and DN127) was confirmed.
\end{abstract}

A large portion of our phylogenetic knowledge in the field of bacterial evolution is based on sequence data for the $16 \mathrm{~S}$ rRNA subunit (56) common to all bacteria. An amazing amount of phylogenetic information, ranging from conserved spots to highly variable spots, is condensed in this genomic region. However, the usefulness of other genomic regions for evolutionary studies of microorganisms has been emphasized in several studies. Following this theme, phylogenies substantially different from the Woese concept have been proposed based on alignments of several housekeeping genes. These include the genes for the $70-\mathrm{kDa}$ heat shock proteins (20), the $60-\mathrm{kDa}$ heat shock proteins (homologs of Escherichia coli GroEL) $(20,52)$, elongation factor EF-Tu (40), glutamate dehydrogenase (7), glutamine synthetase $(10,29,48)$, and RecA (27). These studies and a variety of others have clearly shown that phylogenies based on different genes may differ. Although there are virtually no rational grounds for choosing the right phylogeny, we speculate that a target genomic region for DNA sequence alignment can be more or less suitable for phylogenetic analysis of a particular group of organisms. While some genes might be appropriate for phylogenetic inference at the phylum level, other genes might be more appropriate at lower taxonomic levels, such as the family or genus level. In our phylogenetic approach we have focused on the use of bacterial histone-like proteins (also known as nucleoproteins) for inferring phylogenetic relationships of bacteria at the genus level. Because of the intimate interaction of these proteins with the DNA and a high degree of homology, it has been proposed that the sequences of this type of protein should be used as a tool to study the evolution of the organisms which produce them $(21,38)$. Histone-like proteins are small, basic, heat-

\footnotetext{
* Corresponding author. Mailing address: Istituto Cantonale Batteriosierologico, Via Ospedale 6, CH-6904 Lugano, Switzerland. Phone: 00419192325 22. Fax: 00419192209 93. E-mail: cvalsang@guest .cscs.ch.
}

stable DNA-binding proteins. Among the most common histone-like proteins are major nucleoprotein HU and IHF (the integration host factor in E. coli). Rather than having properties of eucaryotic histones, these proteins occupy a central role in various gene regulation mechanisms $(14,17,42)$. We used this approach to study the phylogenetic relationships of Borrelia burgdorferi sensu lato strains, the causative agents of Lyme disease, which have been the objects of intensive phylogenetic studies over the last few years. Our study was based on an analysis of the sequence of the histone-like $h b b$ gene of reference strain ATCC $35210^{\mathrm{T}}\left(=\mathrm{B} 31^{\mathrm{T}}\right)(\mathrm{T}=$ type strain), which was recently cloned by $\mathrm{K}$. Tilly and coworkers. The recently cloned $h b b$ gene (49) encodes protein $\mathrm{HBb}$ and complements both IHF- and HU-deficient $E$. coli strains by substituting for all IHF and HU activities required for $\lambda$ growth $(21,36)$. In a comparative study performed with related genes in other organisms, the predicted amino acid sequence encoded by the $h b b$ gene of $B$. burgdorferi sensu lato exhibited the highest degrees of similarity with the homologous proteins from Thermus thermophilus and Bacillus subtilis (about $36 \%$ of the amino acids were identical) (49). The $\mathrm{HBb}$ protein appears, therefore, to be a $B$. burgdorferi histone-like protein which has IHF and $\mathrm{HU}$ features.

$B$. burgdorferi, the original species involved in Lyme disease, was named in the early 1980 s after its discoverer, W. Burgdorfer (11), and has been subdivided taxonomically. Several genomic species, including $B$. burgdorferi sensu stricto, Borrelia garinii, Borrelia afzelii, and Borrelia japonica, have been validly described $(6,12,28)$. An association with different chronic manifestations of Lyme disease was found for the first three of these genomic species $(1,2,4,51)$. However, it is possible to distinguish clearly additional genomic species with genetic distances comparable to those observed between the nomenspecies by using multilocus enzyme electrophoresis (MLEE) (5) and other molecular techniques (such as DNA-DNA hybridization [39] or PCR analysis of the $f l a$ gene [3]). We recently proposed a further subdivision of the Lyme spirochetes and 
TABLE 1. Borrelia strains used in this study

\begin{tabular}{|c|c|c|c|c|}
\hline Strain & Division $^{a}$ & Species & Geographic origin & Accession no. ${ }^{b}$ \\
\hline $\operatorname{ATCC} 35210^{\mathrm{T}}\left(=\mathrm{B} 31^{\mathrm{T}}\right)$ & I & B. burgdorferi sensu stricto & United States & U48648 \\
\hline NY1387 & I & B. burgdorferi sensu stricto & United States & U48649 \\
\hline A44S & I & B. burgdorferi sensu stricto & Holland & U48650 \\
\hline $\mathrm{P} 1 \mathrm{G}$ & I & B. burgdorferi sensu stricto & Switzerland & U48651 \\
\hline IP1 & I & B. burgdorferi sensu stricto & France & U48652 \\
\hline IP2 & I & $B$. burgdorferi sensu stricto & France & U48653 \\
\hline IP3 & I & B. burgdorferi sensu stricto & France & U48654 \\
\hline SIKA2 & II & B. garinii & Japan & U48657 \\
\hline SIKA1 & II & B. garinii & Japan & U48656 \\
\hline VSBP & II & B. garinii & Switzerland & $\mathrm{U} 48658$ \\
\hline $\mathrm{P} / \mathrm{Bi}$ & II & B. garinii & Germany & U48659 \\
\hline VS102 & II & B. garinii & Switzerland & U48660 \\
\hline NT29 & III & B. garinii & Japan & U48661 \\
\hline Ip89 & III & B. garinii & Russia & U48662 \\
\hline A19S & III & B. garinii & Holland & U48664 \\
\hline Poti B1 & IV & $\mathrm{NA}^{c}$ & Portugal & U48665 \\
\hline Poti B3 & IV & NA & Portugal & U48667 \\
\hline Poti B2 & IV & NA & Portugal & U48666 \\
\hline VS116 & $\mathrm{V}$ & NA & Switzerland & U48668 \\
\hline UK & $\mathrm{V}$ & NA & England & U48669 \\
\hline $\mathrm{CA} 2$ & VI & NA & United States & $\mathrm{U} 48670$ \\
\hline VS $461^{\mathrm{T}}$ & VII & B. afzelii & Switzerland & U48671 \\
\hline UO1 & VII & B. afzelii & Sweden & U48672 \\
\hline DK8 & VII & B. afzelii & Denmark & U48674 \\
\hline $\mathrm{A} 26 \mathrm{~S}$ & VII & B. afzelii & Holland & U48673 \\
\hline ECM1 & VII & B. afzelii & Sweden & U48675 \\
\hline $\mathrm{BO} 23$ & VII & B. afzelii & Germany & U48676 \\
\hline $\mathrm{HO} 14^{\mathrm{T}}$ & VIII & B. japonica & Japan & U48677 \\
\hline F63B & VIII & B. japonica & Japan & U48678 \\
\hline COW 611A & VIII & B. japonica & Japan & U48679 \\
\hline COW $611 \mathrm{C}$ & VIII & B. japonica & Japan & U48680 \\
\hline O612 & VIII & B. japonica & Japan & U48681 \\
\hline DN127 & IX & $\mathrm{NA}$ & United States & U48683 \\
\hline CA128 & IX & NA & United States & U48684 \\
\hline CA55 & IX & NA & United States & U48663 \\
\hline 25015 & $\mathrm{X}$ & NA & United States & U48685 \\
\hline 19952 & XI & "B. andersonii" & United States & U48686 \\
\hline M3001 & & B. parkeri & United States & $\mathrm{U} 48655$ \\
\hline $0 \mathrm{M} 2007$ & & B. turicatae & United States & U48682 \\
\hline CO53 & & B. coriaceae & United States & \\
\hline HS1 & & B. hermsii & United States & \\
\hline
\end{tabular}

"B. burgdorferi sensu lato division as determined by MLEE (5).

${ }^{b}$ GenBank accession number for the DNA sequence of the $h b b$ gene.

c NA, not assigned to a species at this time.

described seven new genomic groups in addition to the four accepted species (5) on the basis of the results of a MLEE analysis in which 12 enzyme loci were used. A name for the genomic group represented by strain 21123 (division XI in our previous study [5]), "Borrelia andersonii," has been proposed recently (34).

The aim of this study was to determine whether sequence data from a single gene locus encoding an histone-like protein are suitable for estimating phylogenetic relationships in the genus Borrelia.

\section{MATERIALS AND METHODS}

Bacterial strains. A total of 37 B. burgdorferi sensu lato strains from clinical samples and different tick species, as well as single strains of the relapsing fever spirochetes Borrelia turicatae, Borrelia parkeri, Borrelia coriaceae, and Borrelia hermsii, were used in this study (Table 1). The strains used were from many different geographic areas of the world and represented all of the divisions identified by MLEE (5). The Borrelia strains were grown in BSK-H medium (Sigma Chemical Co., St. Louis, Mo.) supplemented with $6 \%$ rabbit serum
(Sigma) at $32^{\circ} \mathrm{C}$ until the medium color turned from red to yellowish as previously described (4).

Construction of PCR primers. A 433-bp DNA fragment containing the 327-bp $h b b$ gene was amplified by using flanking primers containing EcoRI-engineered restriction sites, which were designed by starting with the original sequence of strain ATCC $35210^{\mathrm{T}}\left(=\mathrm{B} 31^{\mathrm{T}}\right.$ ) (sequence kindly provided by $\mathrm{K}$. Tilly, National Institutes of Health, Hamilton, Mont.). The primers used were primer B.1. (5'-GCGAAGAATTCATAAAAATAAGGCTGC-3'; -78 bp upstream of the $h b b$ open reading frame [ORF]) and primer B.r. (5'-TATAAGAATTCACGA TATTAACTGGC-3'; +28 bp downstream) (the underlined sequence is the EcoRI recognition sequence). A pair of nested primers was designed for conserved regions of the $h b b$ gene by starting with the alignment for the 39 isolates. The nested primers used were primer B.l.nest (5'-AGATGCTTTTTTTGAAG AGC-3'; forward primer at positions 114 to 133 of the $h b b$ ORF) and primer B.r.nest (5'-CAAATCTTTGCCTGGACG-3'; reverse primer at positions 297 to 280 of the $h b b$ ORF).

DNA extraction and PCR. DNA was extracted from $50 \mu \mathrm{l}$ of a BSK-H liquid culture by using a commercial ion-exchange resin (InstaGene matrix; Bio-Rad Laboratories, Richmond, Calif.) according to the instructions of the manufacturer. A $10-\mu \mathrm{l}$ portion of DNA extract was used for the PCR in a total reaction volume of $50 \mu \mathrm{l}$. Each reaction mixture also contained $10 \mathrm{mM}$ Tris- $\mathrm{HCl}(\mathrm{pH} 8.3)$, $50 \mathrm{mM} \mathrm{KCl}, 2.5 \mathrm{mM} \mathrm{MgCl}_{2}$, each deoxynucleoside triphosphate at a concentration of $200 \mu \mathrm{M}, 0.01 \%$ gelatin type A (Sigma), each primer at a concentration of $0.5 \mu \mathrm{M}$, and $1 \mathrm{U}$ of Taq polymerase (Boehringer, Mannheim, Germany). The 
reaction mixtures were overlaid with paraffin oil (Merck, Darmstadt, Germany) to prevent evaporation. The thermal profile used was 35 cycles consisting of $94^{\circ} \mathrm{C}$ for $1 \mathrm{~min}, 50^{\circ} \mathrm{C}$ for $1 \mathrm{~min}$, and $72^{\circ} \mathrm{C}$ for $30 \mathrm{~s}$.

DNA sequencing. Templates for cycle sequencing were prepared by purifying PCR products with a Wizard PCR Preps DNA purification system (Promega, Madison, Wis.). Direct sequencing was done with an fmol DNA sequencing system (Promega) by using either primers B.l. and B.r. or a second set of nested primers (see above).

Analysis of nucleotide sequences. DNA nucleotide and amino acid sequences were stored and handled with the PC/GENE (version 6.8) sequence analysis program (IntelliGenetics, Inc., Geel, Belgium). A phylogenetic analysis of the sequence data was performed by using both CLUSTALW (a newer version of CLUSTAL [22]), which was based on the method of Higgins and Sharp (23), and DRAWTREE, which is included in the PHYLIP package (16). The conditions used for alignment were as follows: K-tuple value, 2; gap penalty, 10; gap extension penalty, 0.10 (although no gaps were present in the alignment); and window size, 10. In addition, transitions were weighted twice as likely as transversions

Nucleotide sequence accession numbers. The original $h b b$ sequence of reference strain ATCC $35210^{\mathrm{T}}\left(=\mathrm{B} 31^{\mathrm{T}}\right)$ of $B$. burgdorferi sensu stricto has been deposited in the GenBank database under accession number U35673. The accession numbers of the $h b b$ gene sequences generated in this study are listed in Table 1.

\section{RESULTS AND DISCUSSION}

$\boldsymbol{h} \boldsymbol{b} \boldsymbol{b}$ gene. A 433-bp fragment containing the $h b b$ gene (length, $327 \mathrm{bp}$ ) was amplified for each isolate in a collection containing more than $60 \mathrm{~B}$. burgdorferi sensu lato strains (data not shown). The same amplification product was generated from the relapsing fever agents $B$. turicatae and $B$. parkeri, but not from $B$. coriaceae and $B$. hermsii, suggesting that there was a lower degree of conservation of the flanking regions in isolates of the last two species. The length of the $h b b$ gene (327 bp) was perfectly conserved in all of the isolates sequenced; no deletions or insertions were observed.

We computed the isoelectric points for the enzymes deduced from the amino acid sequences obtained for the collection of strains. This physicochemical parameter is an important feature of DNA-binding proteins; because of their function, these proteins are characterized by high isoelectric values. The values deduced for the $h b b$ gene products matched the values found for other proteins of the same family and ranged from $\mathrm{pH} 10.47$ to 10.95 ; the values for most of the strains were around $\mathrm{pH} 10.8$. As expected, the $\mathrm{G}+\mathrm{C}$ content of the $h b b$ gene, as calculated from the DNA sequence data in Fig. 1A through $\mathrm{C}$, accounted for $30.65 \%$ of the total nucleotides (average for the 39 strains sequenced), which mirrored the average content of 28 to $30.1 \%$ for the whole genome of $B$. burgdorferi sensu lato described elsewhere (24). The nucleotide at the wobble position of the preferentially used codons was more often an A or U (33.9 and $44 \%$, respectively) than a $\mathrm{G}$ or $\mathrm{C}$ ( 15.5 and $6.4 \%$, respectively), as has been postulated previously for organisms with low $\mathrm{G}+\mathrm{C}$ contents (25).

In the strain collection studied ( $B$. burgdorferi sensu lato, $B$. turicatae, and $B$. parkeri), overall, 81 nucleotide substitutions that were responsible for 25 substitutions at the deduced amino acid level were found within the 327 nucleotides composing the $h b b$ gene.

The differences in nucleotide sequences between the $h b b$ genes were not evenly distributed among all three codon positions; of the 81 substitutions, 17 were in the first codon position, 12 were in the second codon position, and 52 were in the third codon position. This result can be considered a natural outcome of degeneracy of the genetic code. When the $B$. burgdorferi sensu lato strains alone were considered and the sequences of the strains of the relapsing fever spirochetes $B$. parkeri and $B$. turicatae were not taken into account, the overall numbers of mutations dramatically decreased to 55 nucleotide substitutions and 15 amino acid substitutions. The two non-
Lyme disease spirochetes are therefore clearly distinct from the cluster represented by $B$. burgdorferi sensu lato strains (Fig. 2).

$h b b$ sequence analysis versus MLEE and DNA-DNA hybridization. From the alignment of the nucleotide sequences of 39 strains (Fig. 1) a distance matrix of identity (Fig. 3) and an unrooted phylogenetic tree (Fig. 2) were generated. In order to assess the robustness of the phylogenetic tree inferred from the DNA alignment (Fig. 2), data from the $h b b$ sequence analysis were compared with data derived by using two additional methods, MLEE (5) and DNA-DNA hybridization (6). MLEE, whose results have been shown to match the species identification results obtained by DNA-DNA-hybridization (6, $8,9)$, is widely considered one of the methods of choice for characterizing bacterial populations at the species level (43). The clustering obtained by aligning the $h b b$ gene sequences was largely in agreement with information generated by the other two methods, particularly the dendrogram generated by MLEE data. Clusters containing $B$. burgdorferi sensu stricto, $B$. afzelii, B. japonica, group PotiB1, and group VS116 were clearly differentiated by all three methods. The results for strains CA2 and 25015 and the group formed by strains NT29, A19S, and Ip89 exhibited discrepancies if they were compared with the results of other typing methods. In this work, strain CA2 could be clearly separated from the group represented by strain 19952. This result is consistent with MLEE analysis results but is not consistent with DNA-DNA hybridization data. However, when the latter technique was used, strain CA2 had the lowest value in its group (level of DNA relatedness, $73 \%$ ). Likewise, MLEE data and the results of this study showed that strain 25015 is the prototype of another genomic group, while hybridization data assigned this strain to the group containing strain DN127. When the classification of the group formed by strains NT29, A19S, and Ip89 was examined, our data confirmed previous findings of other authors who assigned these strains to the species $B$. garinii $(18,39)$; on the other hand, this result is not consistent with the MLEE data, which suggests that these organisms belong to a new genomic group. A more substantial difference between the dendrogram based on MLEE data and the dendrogram based on alignment of the $h b b$ gene sequences is related to the classification of the relapsing fever spirochetes. Whereas on the MLEE-derived phylogenetic tree $B$. parkeri, $B$. turicatae, and $B$. hermsii were not separated clearly from the spirochetes associated with Lyme disease, on the tree derived from $h b b$ sequence data $B$. turicatae and $B$. parkeri were a significant distance from the entire cluster of Lyme disease spirochetes. The classification of the relapsing fever spirochetes has been controversial in recent years. Noppa et al. (37) used $f l a$ gene sequences to classify these organisms in a group separate from the Lyme disease spirochetes, but Livesley et al. (30) classified them with the Lyme disease spirochetes on the basis of the results of an analysis of fatty acid methyl esters. Additional sequence analyses based on other genomic regions should be performed to explain these differences.

$h b b$ gene product versus known histone-like proteins. Protein $\mathrm{HBb}$, which is encoded by the $h b b$ gene, is larger (length, 108 residues) than other members of the family of histone-like proteins (length, roughly 90 residues). Several residues involved in the biological function of histone-like proteins, such as residues of the hydrophobic core and residues of the DNAbinding arm, are highly conserved across bacterial species (45). This feature is also found in Borrelia isolates; residues found to be involved in the hydrophobic core of the protein are conserved both between Borrelia and other species and also across all Borrelia isolates analyzed. In particular, seven of eight res- 
A

B31

NY1387

A44S

P1G
IP1

IP2

IP3

BPAR

SIKA1

SIKA2

VSBP

PBI

vS102

NT29

IP89

A19S

POTIB1

POTIB2

POTIB3

VS116

CA2

vS461

vo1

DK8

ECM1

A26S

BO23

HO14

F63B

cow611

0612

BTUR

DN127

CA128

CA55

25015

19952

\section{B}

B31

NY1387

A44S

IP1

IP2

BPAR

SIKA1

SIKA2

VSBP

PBI

vS102

NT29

IP89

A19S

POTIB1

POTIB2

POTIB

VS116

UK

CA2

vS461

U01

DK8

ECM1

BO23

Ho14

F63B

Cow611A

Cow611

0612

BTUR

DN127

CA128

25015

19952

FIG. 1. Alignments of the nucleotide (A through C) and deduced amino acid (D) sequences of the $h b b$ gene and HBb protein from 39 Borrelia strains. A dash indicates that a position in the alignment is conserved. In panel $\mathrm{D}$ the underlined residues are residues involved in the hydrophobic core of the protein and the sequence enclosed in a box is the signature for histone-like proteins located on the putative DNA-binding arm.

ATGTCTTTTTCAAGAAGACCAAAGGTTACTAAGTCAGACATTGTTGATCAAATAGCTTTGAATATTAAAAATAATAATCTGAAAT TAGAAAAAAAATACATAAGACTTGTAATAGATGCT
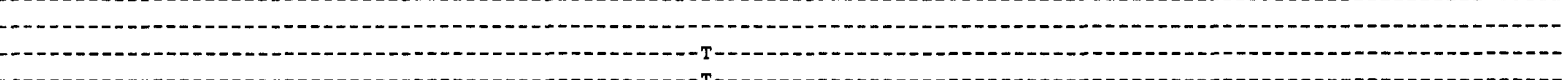

-

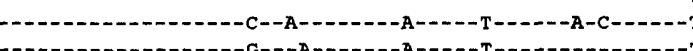

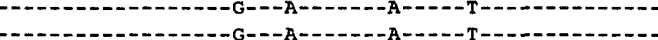

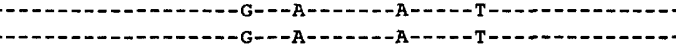

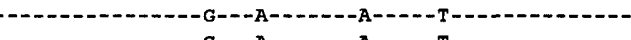
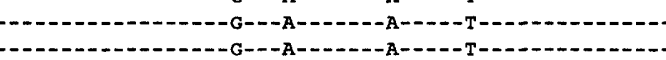

TTTTTGAAGAGCTTAAAAGTAATCTTTGTTCGAATAATGTTATTGAGTTTAGATCTTTTGGTACATTTGAAGTTAGAAAAAGAAAGGGACGCT TAAATGCTCGAAATCCTCAAACAGGG

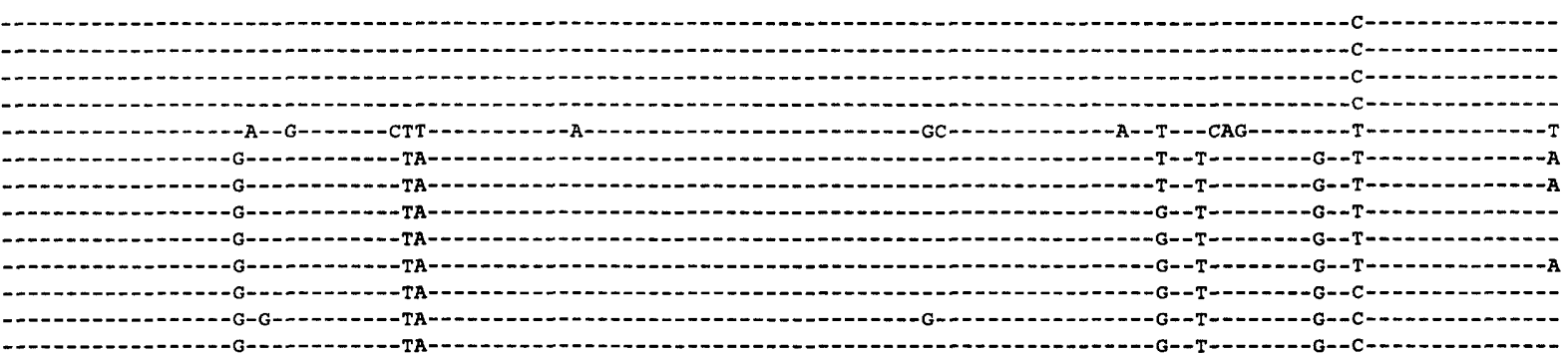

-1
-1

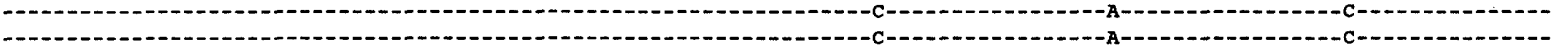
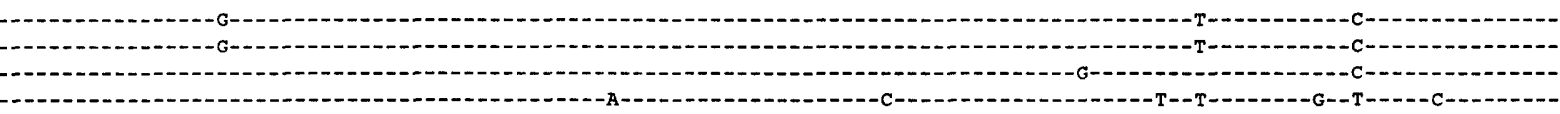
-1
-1

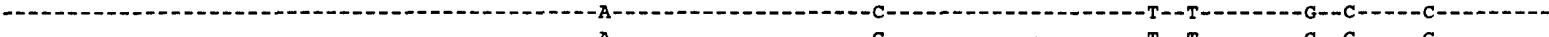

-1
-1

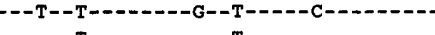

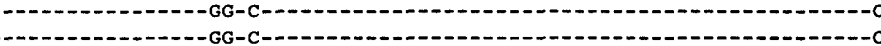

-

(1)

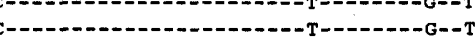

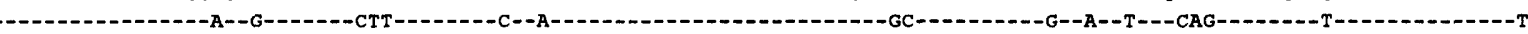


c

B31 GAGTATGTTAAGGTCCTAGATCATCACGTTGCGTATTTTCGTCCAGGCAAAGATTTGAAAGAGAGAGTGGGGGTATCAAAGGTTAA

NY1387 -T---

A44S $\quad$ S

P1G -

IP1 -

IP2 -

IPPAR - 3 -

SIKA1 --A-D-1

SIKA2 - - A-

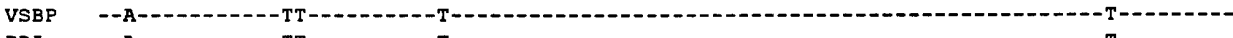

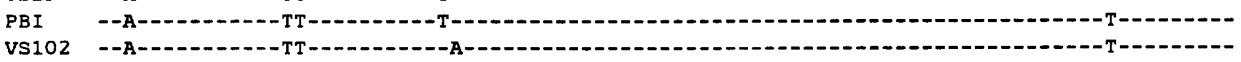

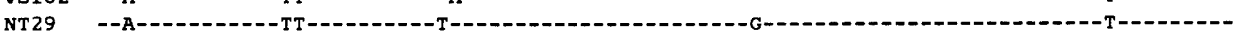

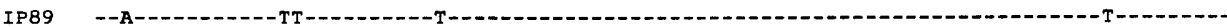

A19S - $\mathrm{A}-1-2-1$

POTIB1 -

РОTIB2 -

РОТ ІВЗ --

VS116 --A-16-1-1

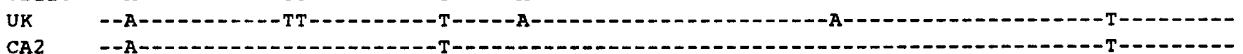

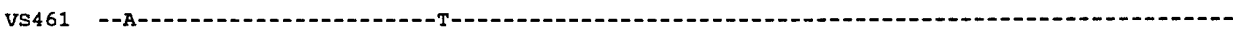

UO1 --A-1

DK8 - -A-1-

ECM1 - - A-

A26S --A-1--

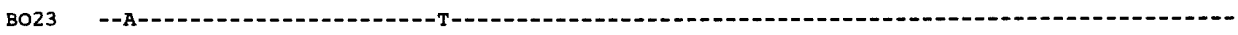

HO14 -

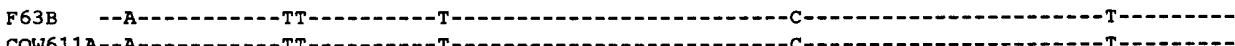

COW611A--A-

COW611C--A-12 - A- 0612

BTUR - -

DN127 - A-_._.

CA128 --A---1--

CA55 - A

19952 --A--

D 31

NY1387

$\mathrm{A} 44 \mathrm{~S}$

P1G

IP1

IP2

IP 3

BPAR

SIKA1

SIKA2

VSBP

PBI

VS102

NT 29

IP89

A19S

POTIB1

POTIB2

POT IB 3

VS116

UK

CA2

vS4 61

บo1

A26\$

DK8

ECM1

$\mathrm{BO} 23$

H014

F631

Cow611A

Cow $\$ 11 \mathrm{C}$

0612

BTUR

DN127

CA128

CA55

25015

19952
5

MSFSRRPKVTKSDIVDQIALNI KNNNLKLEKKYIRLVI DAFFEELKSNLCSNNVIEFF SFGTFEVRKRKGRLNARNPQTIGEYVKVLDHHVAYFRPGKDLKERVWGIKG

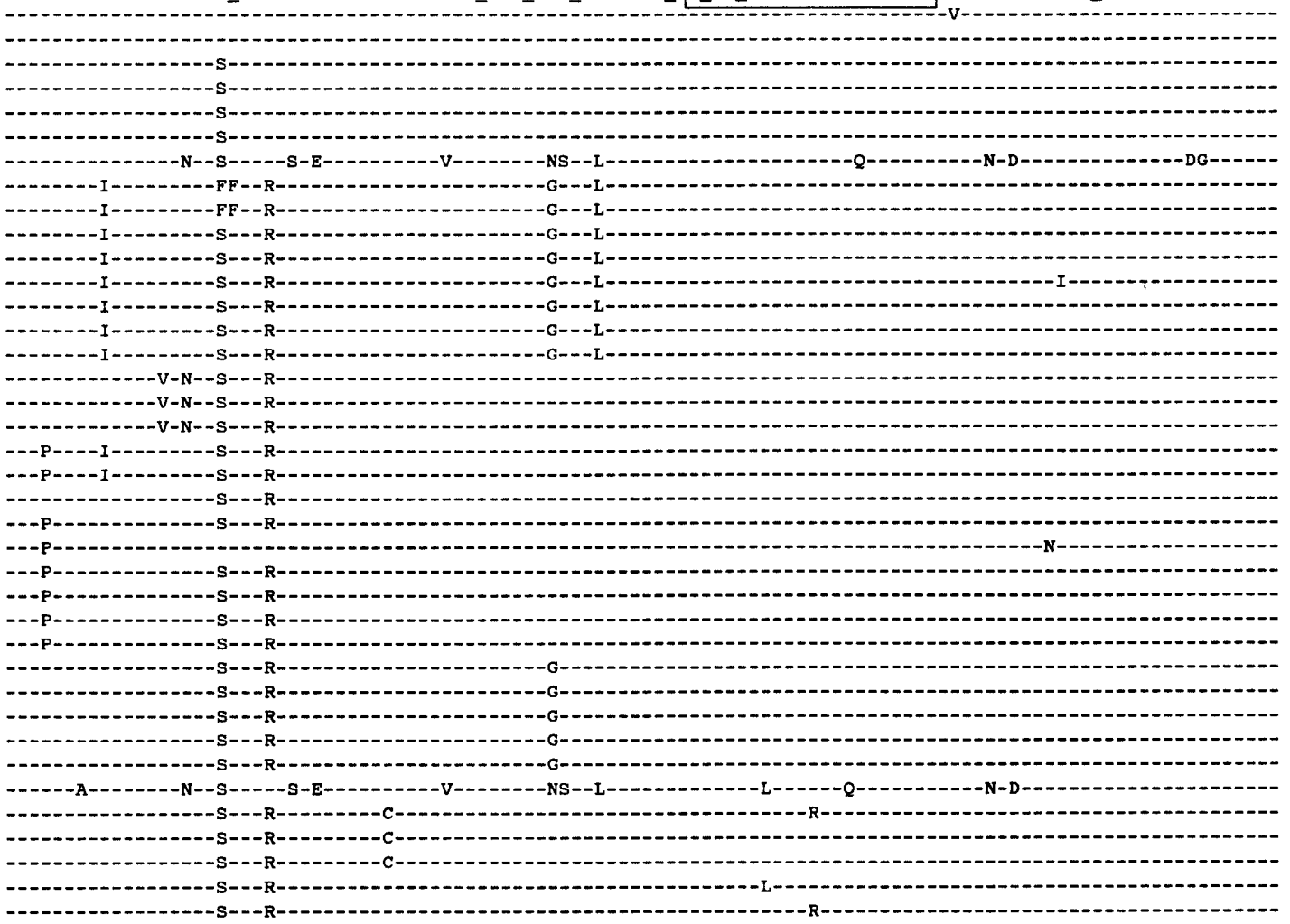

FIG. 1-Continued. 


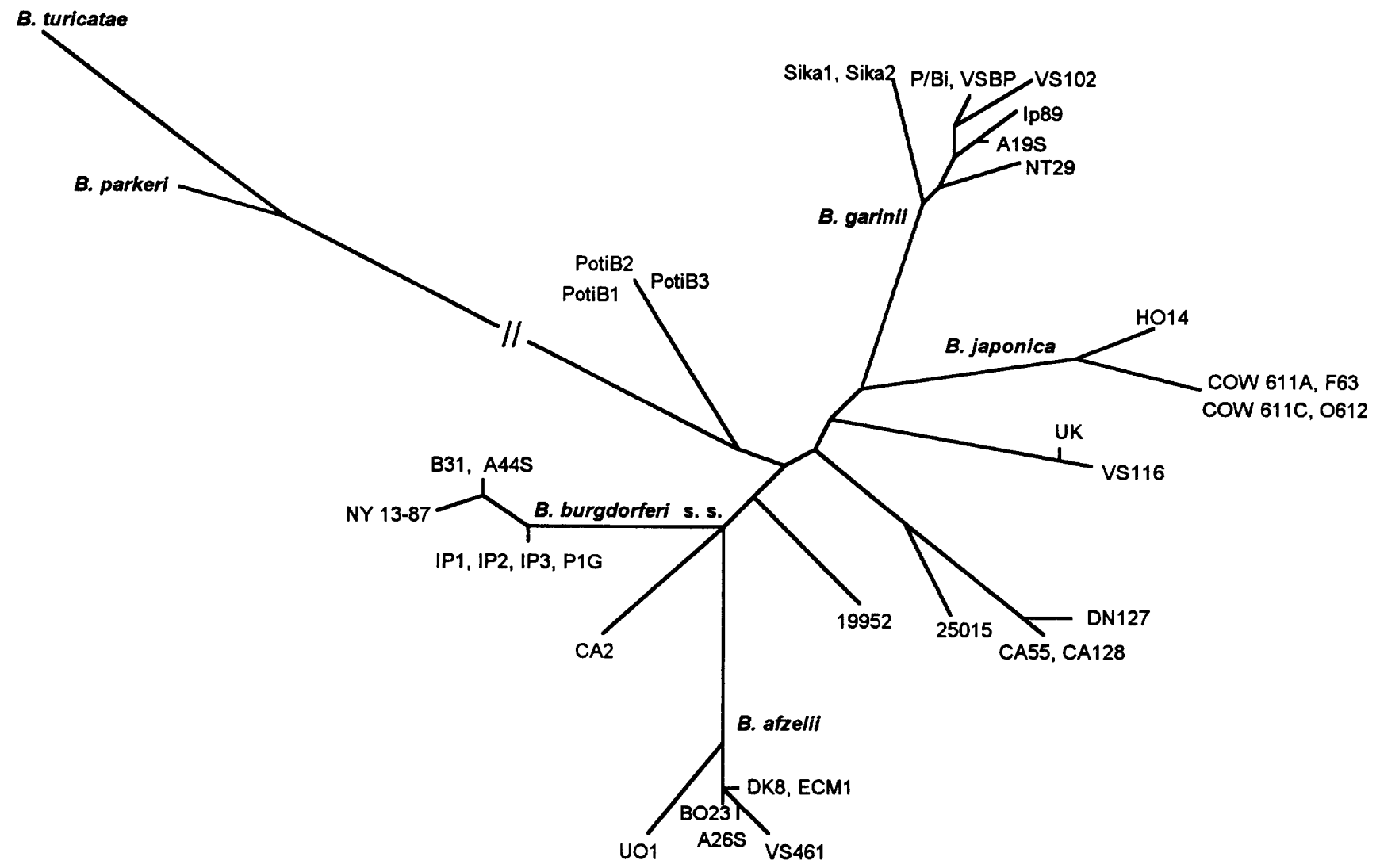

FIG. 2. Unrooted phylogenetic tree based on nucleotide sequences of the $h b b$ gene. The method used for drawing the tree was DRAWTREE, a program included in the software package PHYLIP. B. burgdorferi s.s., B. burgdorferi sensu stricto.

idues of the hydrophobic core (phenylalanine residues 41,57 , 60,63 , and 93 and leucine residues 45 and 49) are perfectly conserved, while leucine- 20 is replaced by phenylalanine (also a hydrophobic amino acid) in two strains (SIKA1 and SIKA2).

We searched the ProDom protein domain database (which consists of an automatic compilation of homologous domains detected in the SWISS-PROT database) by using the DOMAINER algorithm (44) for a signature sequence for histonelike proteins. We found a signature sequence consisting of 20 residues which includes three perfectly conserved positions. This signature sequence is [GS]-F-X(2)-[LIVMF]-X(4)[RKEQA]-X(2)-[RST]-X-[GA]-X-[KN]-P-X-T. It is predicted that this region forms the first half of the flexible DNA-binding arm according to the tertiary structure of one of the proteins proposed by Tanaka et al. (45) and, therefore, should be fairly well conserved. In all of the Borrelia strains analyzed in this study, the sequence of 21 residues (from position 59 to position 79) matched the signature sequence for histone-like proteins, with the exception of a single amino acid position (a gap was inserted in the original consensus sequence so that it would be aligned with Borrelia sequences). Particularly invariant amino acid residues were found in this region. Although rich in variation at the nucleotide level (14 substitutions in 63 nucleotides), this region was well conserved at the amino acid level (3 substitutions in 21 residues), which led to four unique sequences (one found in B. parkeri and B. turicatae, one found in strains 19952 and DN127, one found in strain 25015, and one found in all of the other B. burgdorferi sensu lato strains analyzed). All of the substitutions found in the Borrelia isolates at the deduced amino acid level were located in variable regions of the signature (Table 2).

Furthermore, the signatures of 21 previously published sequences determined for histone-like proteins of different organisms (including gram-positive and gram-negative bacteria, as well as one species of cyanobacteria [Anabaena sp.], one chloroplast [from Cryptomonas sp.], and bacteriophage SPO1) were aligned with Borrelia sequences (Table 2). The dendrogram constructed from this alignment (Fig. 4) revealed that there is a clear difference between protein $\mathrm{HBb}$ of Borrelia strains and the histone-like proteins of other organisms. Whether $\mathrm{HBb}$ represents a new type of histone-like protein or reflects an evolutionarily early divergence from the family remains an open question. A possible explanation for this observation might be related to some peculiarities of the DNA structure found in these spirochetes. The predominant form of DNA found in borreliae (but not in most of the other organisms) is in fact linear, with covalently closed ends. Thus, the requirements for DNA condensation and replication might be different in Borrelia strains than in other organisms. The functions fulfilled by IHF and HU in other organisms (e.g., E. coli) might be accomplished by a single protein in these spirochetes.

$\boldsymbol{h} \boldsymbol{b} \boldsymbol{b}$ gene versus other Borrelia genes. The robustness of DNA sequence analysis for phylogenetic purposes is guaranteed when the appropriate analysis tools (algorithms for data processing) and a representative collection of strains are carefully selected. However, the most crucial element for correct phylogenetic extrapolations is the choice of a suitable target genomic region. In the case of a coding region, the gene should 


\begin{tabular}{|c|c|c|c|c|c|c|c|c|c|c|c|c|c|c|c|c|c|c|c|c|c|c|c|c|c|c|}
\hline & 1 & 2 & 3 & 4 & 5 & 6 & 7 & 8 & 9 & 10 & 11 & 12 & 13 & 14 & 15 & 16 & 17 & 18 & 19 & 20 & 21 & 22 & 23 & 24 & 25 & 26 \\
\hline 1 & & 326 & 325 & 318 & 313 & 312 & 311 & 311 & 310 & 314 & 310 & 310 & 309 & 311 & 310 & 308 & 311 & 306 & 306 & 305 & 306 & 306 & 305 & 310 & 282 & 277 \\
\hline 2 & 99.7 & & 324 & 317 & 312 & 311 & 310 & 310 & 300 & 313 & 300 & 300 & 308 & 10 & 309 & 307 & 310 & 305 & 305 & 304 & 305 & 305 & 304 & 300 & 281 & 276 \\
\hline 3 & 99.4 & 98.1 & & 320 & 313 & 313 & 313 & 312 & 312 & 316 & 312 & 312 & 311 & 313 & 312 & 300 & 312 & 300 & 308 & 307 & 307 & 307 & 306 & 312 & 283 & 278 \\
\hline 4 & 97.2 & 96.8 & 97.9 & & 314 & 312 & 314 & 313 & 315 & 317 & 313 & 313 & 312 & 314 & 313 & 310 & 315 & 311 & 311 & 310 & 300 & 310 & 309 & 311 & 284 & 281 \\
\hline 5 & 95.7 & 95.4 & 85.7 & 96.0 & & 319 & 321 & 320 & 322 & 308 & 308 & 307 & 307 & 311 & 310 & 309 & 308 & 307 & 307 & 306 & 304 & 306 & 306 & 306 & 279 & 274 \\
\hline 6 & 95.4 & 85.1 & 95.7 & 95.4 & 97.6 & & 325 & 326 & 324 & 310 & 310 & 300 & 309 & 313 & 312 & 313 & 310 & 300 & 300 & 308 & 308 & 310 & 310 & 300 & 279 & 274 \\
\hline 7 & 95.1 & 84.8 & 95.7 & 96.0 & 98.2 & 99.4 & & 326 & 326 & 310 & 310 & 300 & 309 & 313 & 312 & 311 & 308 & 300 & 300 & 300 & 306 & 306 & 300 & 308 & 279 & 274 \\
\hline 8 & 95.1 & 84.8 & 95.4 & 85.7 & 97.9 & 89.7 & 99.7 & & 325 & 300 & 300 & 308 & 308 & 312 & 311 & 312 & 300 & 308 & 306 & 307 & 307 & 300 & 300 & 307 & 280 & 275 \\
\hline 9 & 94.8 & 24.5 & 85.4 & 96.3 & 98.5 & 99.1 & 99.7 & 99.4 & & 311 & 311 & 310 & 310 & 314 & 313 & 312 & 300 & 310 & 310 & 300 & 307 & 300 & 300 & 300 & 280 & 275 \\
\hline 10 & 96.0 & 85.7 & 96.6 & 96.9 & 94.2 & 94.8 & 94.8 & 24.5 & 95.1 & & 315 & 315 & 316 & 315 & 314 & 310 & 311 & 310 & 310 & 307 & 305 & 307 & 308 & 300 & 283 & 278 \\
\hline 11 & 84.8 & 24.5 & 85.4 & 85.7 & 94.2 & 94.8 & 94.8 & 24.5 & 95.1 & 96.3 & & 321 & 320 & 315 & 314 & 314 & 315 & 311 & 311 & 300 & 306 & 308 & 308 & 311 & 284 & 278 \\
\hline 12 & 94.8 & 94.5 & 95.4 & 85.7 & 93.8 & 84.5 & 94.5 & 84.2 & 94.8 & 86.3 & 98.2 & & 325 & 315 & 314 & 312 & 313 & 313 & 313 & 310 & 308 & 310 & 300 & 300 & 280 & 278 \\
\hline 13 & 84.5 & 84.2 & 85.1 & 95.4 & 93.8 & 94.5 & 94.5 & 94.2 & 94.8 & 96.6 & 97.8 & 99.4 & & 314 & 313 & 311 & 312 & 311 & 311 & 308 & 306 & 308 & 300 & 308 & 280 & 278 \\
\hline 14 & 85.1 & 94.8 & 85.7 & 96.0 & 95.1 & 95.7 & 95.7 & 95.4 & 96.0 & 96.3 & 86.3 & 96.3 & 96.0 & & 328 & 315 & 314 & 314 & 314 & 313 & 311 & 313 & 312 & 314 & 280 & 278 \\
\hline 15 & 94.8 & 94.5 & 95.4 & 95.7 & 94.8 & 95.4 & 95.4 & 95.1 & 85.7 & 96.0 & 96.0 & 96.0 & 95.7 & 99.7 & & 314 & 313 & 313 & 313 & 312 & 310 & 312 & 311 & 313 & 282 & 277 \\
\hline 16 & 94.2 & 93.8 & 94.5 & 94.8 & 94.5 & 95.7 & 85.1 & 85.4 & 95.4 & 94.8 & 96.0 & 95.4 & 95.1 & 96.3 & 96.0 & & 322 & 314 & 312 & 312 & 311 & 313 & 312 & 310 & 278 & 273 \\
\hline 17 & 85.1 & 94.8 & 85.4 & 96.3 & 94.2 & 94.8 & 84.2 & 94.5 & 94.5 & 95.1 & 96.3 & 95.7 & 95.4 & 96.0 & 95.7 & 98.5 & & 313 & 311 & 311 & 310 & 312 & 311 & 300 & 278 & 274 \\
\hline 18 & 93.6 & 83.3 & 94.2 & 95.1 & 93.9 & 94.5 & 94.5 & 94.2 & 94.8 & 94.8 & 95.1 & 95.7 & 85.1 & 96.0 & 95.7 & 96.0 & 95.7 & & 325 & 322 & 320 & 322 & 320 & 307 & 282 & $2 \pi$ \\
\hline 19 & 93.6 & 93.3 & 94.2 & 95.1 & 83.9 & 94.5 & 94.5 & 94.2 & 94.8 & 84.8 & 95.1 & 95.7 & 85.1 & 96.0 & 95.7 & 95.4 & 95.1 & 98.4 & & 324 & 322 & 324 & 320 & 307 & 282 & 277 \\
\hline 20 & 93.3 & 93.0 & 93.9 & 94.8 & 93.6 & 94.2 & 94.2 & 93.8 & 94.5 & 83.8 & 24.5 & 94.8 & 94.2 & 95.7 & 95.4 & 95.4 & 85.1 & 98.5 & 99.1 & & 321 & 323 & 319 & 306 & 283 & 278 \\
\hline 21 & 93.6 & 83.3 & 93.9 & 94.2 & 93.0 & 94.2 & 93.6 & 93.9 & 93.9 & 93.3 & 93.6 & 94.2 & 93.6 & 95.1 & 94.8 & 95.1 & 94.8 & 97.8 & 98.5 & 98.2 & & 323 & 321 & 304 & 282 & $2 \pi$ \\
\hline 22 & 83.6 & 93.3 & 93.8 & 94.8 & 93.6 & 94.6 & 94.2 & 84.5 & 94.5 & 83.8 & 94.2 & 94.8 & 94.2 & 95.7 & 95.4 & 95.7 & 95.4 & 98.5 & 89.1 & 98.8 & 98.8 & & 321 & 308 & 285 & 280 \\
\hline 23 & 93.3 & 93.0 & 93.6 & 94.5 & 93.6 & 94.8 & 94.2 & 94.5 & 94.5 & 83.6 & 94.2 & 84.5 & 94.5 & 95.4 & 95.1 & 95.4 & 95.1 & 97.8 & 87.9 & 97.6 & 88.2 & 98.2 & & 305 & 285 & 280 \\
\hline 24 & 94.8 & 94.5 & 85.4 & 95.1 & 93.6 & 94.2 & 94.2 & 93.8 & 24.5 & 94.5 & 85.1 & 84.5 & 94.2 & 96.0 & 95.7 & 94.8 & 94.5 & 93.8 & 93.9 & 93.6 & 93.0 & 93.6 & 83.3 & & 285 & 280 \\
\hline 25 & 86.2 & 85.8 & 88.5 & 86.9 & 85.3 & B5.3 & 85.3 & 85.6 & 85.6 & 86.5 & 86.9 & 86.5 & 86.5 & 86.5 & 86.2 & 85.0 & 85.3 & 88.2 & 88.2 & 86.5 & 86.2 & 87.2 & 87.2 & 87.2 & & 316 \\
\hline 2 & 84.7 & 84.4 & 85.0 & 85.9 & 83.8 & B3.8 & 83.8 & 84.1 & 84.1 & 85.0 & 85.3 & 85.0 & 85.0 & 85.0 & 84.7 & 83.5 & 83.8 & 84.7 & 84.7 & 85.0 & 84.7 & 85.6 & 85.6 & 85.6 & 96.6 & \\
\hline
\end{tabular}

\begin{tabular}{|c|c|c|c|c|c|c|c|c|c|c|c|c|c|c|c|c|c|c|c|c|c|c|c|c|c|c|}
\hline & 1 & 2 & 3 & 4 & 5 & 6 & 7 & 8 & 9 & 10 & 11 & 12 & 13 & 14 & 15 & 16 & 17 & 18 & 19 & 20 & 21 & 22 & 23 & 24 & 25 & 26 \\
\hline 1 & & 107 & 107 & 106 & 108 & 105 & 105 & 105 & 105 & 105 & 105 & 105 & 104 & 104 & 104 & 105 & 105 & 103 & 103 & 103 & 102 & 103 & 102 & 104 & 94 & 95 \\
\hline 2 & 98.1 & & 106 & 105 & $\$ 05$ & 104 & 104 & 104 & 104 & 104 & 104 & 104 & 103 & 103 & 103 & 104 & 104 & 102 & 102 & 102 & 101 & 102 & 101 & 103 & 83 & 94 \\
\hline 3 & 99.1 & 88.1 & & 107 & 105 & 106 & 106 & 106 & 106 & 106 & 106 & 106 & 105 & 105 & 105 & 106 & 106 & 104 & 104 & 104 & 103 & 104 & 102 & 105 & 95 & 96 \\
\hline 4 & 98.1 & 97.2 & 99.1 & & 104 & 107 & 107 & 107 & 107 & 107 & 107 & 107 & 106 & 106 & 106 & 107 & 107 & 105 & 105 & 105 & 104 & 105 & 103 & 100 & 94 & 95 \\
\hline 5 & 88.1 & 97.2 & 97.2 & 96.3 & & 105 & 105 & 105 & 105 & 103 & 103 & 103 & .102 & 104 & 104 & 103 & 103 & 101 & 101 & 101 & 100 & 101 & 100 & 102 & 92 & 93 \\
\hline 6 & 97.2 & 96.3 & 98.1 & 99.1 & 97.2 & & 108 & 108 & 108 & 108 & 106 & 106 & 105 & 107 & 107 & 108 & 108 & 104 & 104 & 104 & 103 & 104 & 102 & 105 & 93 & 84 \\
\hline 7 & 97.2 & 96.3 & 98.1 & 99.1 & 97.2 & 100 & & 108 & 108 & 108 & 106 & 106 & 105 & 107 & 107 & 106 & 100 & 104 & 104 & 104 & 103 & 104 & 102 & 105 & 93 & 94 \\
\hline 8 & 97.2 & 96.3 & 98.1 & 99.1 & 97.2 & 100 & 100 & & 108 & 106 & 108 & 106 & 105 & 107 & 107 & 108 & 106 & 104 & 104 & 104 & 103 & 104 & 102 & 105 & 93 & 94 \\
\hline 9 & 87.2 & 96.3 & 88.1 & 98.1 & 97.2 & 100 & 100 & 100 & & 108 & 108 & 108 & 105 & 107 & 107 & 106 & 106 & 104 & 104 & 104 & 103 & 104 & 102 & 105 & 93 & 24 \\
\hline 10 & 97.2 & 96.3 & 88.1 & 99.1 & 95.4 & 98.1 & 98.1 & 98.1 & 98.1 & & 108 & 106 & 107 & 105 & 105 & 100 & 108 & 104 & 104 & 104 & 103 & 104 & 102 & 105 & 93 & 24 \\
\hline 11 & 97.2 & 96.3 & 88.1 & 99.1 & 95.4 & 98.1 & 98.1 & 88.1 & 98.1 & 88.1 & & 106 & 105 & 105 & 105 & 106 & 108 & 104 & 104 & tou & 103 & 104 & 102 & 105 & 85 & 80 \\
\hline 12 & 87.2 & 96.3 & 88.1 & 99.1 & 95.4 & 98.1 & 88.1 & 88.1 & 88.1 & 88.1 & 98.1 & & 107 & 105 & 105 & 108 & 106 & 104 & 104 & 104 & 103 & 104 & 102 & 105 & 93 & 94 \\
\hline 13 & 98.3 & 85.4 & 87.2 & 98.1 & 94.4 & 97.2 & 87.2 & 97.2 & 97.2 & 89.1 & 97.2 & 99.1 & & 104 & 104 & 105 & 105 & 103 & 103 & 103 & 102 & 103 & 101 & 104 & 82 & 83 \\
\hline 14 & 98.3 & 85.4 & 97.2 & 98.1 & 96.3 & 98.1 & 98.1 & 99.1 & 99.1 & 87.2 & 97.2 & 97.2 & 96.3 & & 108 & 105 & 105 & 105 & 105 & 105 & 104 & 105 & 103 & 104 & 92 & 93 \\
\hline 15 & 96.3 & 95.4 & 97.2 & 98.1 & 96.3 & 99.1 & 88.1 & 99.1 & 99.1 & 87.2 & 87.2 & 97.2 & 96.3 & 100 & & 105 & 105 & 105 & 105 & 105 & 104 & 105 & 103 & 104 & 92 & 93 \\
\hline 16 & 97.2 & 96.3 & 98.1 & 99.1 & 95.4 & 98.1 & 98.1 & 98.1 & 88.1 & 88.1 & 88.1 & 98.1 & 87.2 & 97.2 & 87.2 & & 108 & 106 & 106 & 106 & 105 & 106 & 104 & 105 & 94 & 85 \\
\hline 17 & 97.2 & 96.3 & 88.1 & 99.1 & 95.4 & 98.1 & 98.1 & 98.1 & 98.1 & 98.1 & 98.1 & 98.1 & 97.2 & 97.2 & 97.2 & 100 & & 106 & 106 & 106 & 105 & 108 & 104 & 105 & 94 & 95 \\
\hline 18 & 95.4 & 204 & 96.3 & 97.2 & 93.5 & 96.3 & 96.3 & 96.3 & 96.3 & 96.3 & 96.3 & 96.3 & 95.4 & 97.2 & 97.2 & 98.1 & 98.1 & & 108 & 108 & 107 & 108 & 108 & 103 & 94 & 95 \\
\hline 19 & 95.4 & 201.4 & 96.3 & 97.2 & 93.5 & 96.3 & 96.3 & 96.3 & 96.3 & 96.3 & 96.3 & 96.3 & 95.4 & 97.2 & 97.2 & 98.1 & 98.1 & 100 & & 108 & 107 & 108 & 108 & 103 & 94 & 95 \\
\hline 20 & 95.4 & 94.4 & 96.3 & 97.2 & 93.5 & 96.3 & 96.3 & 96.3 & 86.3 & 96.3 & 96.3 & 96.3 & 95.4 & 97.2 & 97.2 & 98.1 & 98.1 & 100 & 100 & & 107 & 108 & 106 & 103 & 94 & 85 \\
\hline 21 & 94.4 & 93.5 & 85.4 & 96.3 & 92.6 & 95.4 & 95.4 & 95.4 & 95.4 & 95.4 & 85.4 & 95.4 & 94.4 & 86.3 & 86.3 & 87.2 & 97.2 & 89.1 & 99.1 & 99.1 & & 107 & 105 & 102 & 93 & 84 \\
\hline 22 & 85.4 & 24.4 & 96.3 & 97.2 & 93.5 & 96.3 & 96.3 & 96.3 & 96.3 & 86.3 & 86.3 & 96.3 & 85.4 & 97.2 & 97.2 & 98.1 & 88.1 & 100 & 100 & 100 & 89.1 & & 106 & 103 & 94 & 85 \\
\hline 23 & 94.4 & 93.5 & 24.4 & 95.4 & 92.6 & 94.4 & $\$ 0.4$ & 94.4 & 94.4 & 84.4 & 84.4 & 94.4 & 93.5 & 95.4 & 85.4 & 96.3 & 86.3 & 88.1 & 88.1 & 88.1 & 97.2 & 98.1 & & 101 & 92 & 83 \\
\hline 24 & 96.3 & 95.4 & 97.2 & 98.1 & 94.4 & 97.2 & 87.2 & 87.2 & 97.2 & 97.2 & 97.2 & 97.2 & 96.3 & 96.3 & 86.3 & 97.2 & 97.2 & 85.4 & 95.4 & 95.4 & 84.4 & 95.4 & 83.5 & & 24 & 85 \\
\hline 60 & 87 & 86.1 & 88 & 87 & 85.2 & 86.1 & 86.1 & 86.1 & 86.1 & 88.1 & 88 & 86.1 & 85.2 & 85.2 & 85.2 & 87 & 87 & 87 & 87 & 87 & 86.1 & 87 & 85.2 & 87 & & 105 \\
\hline & $B B$ & 87 & 88.8 & 88 & 86.1 & 87 & 87 & 87 & 87 & 87 & 88.9 & 87 & 86.1 & 86.1 & 86.1 & 88 & 88 & 88 & 88 & 88 & 87 & 88 & B6.1 & 88 & 78 & \\
\hline
\end{tabular}

FIG. 3. Matrix of pairwise identity scores for 26 unique nucleic acid sequences (A) and deduced amino acid sequences (B). 1 , reference strain ATCC $35210^{\mathrm{T}}$ $\left(=\mathrm{B} 31^{\mathrm{T}}\right.$ ) and A44S; 2 , NY1387; 3, P1G, IP1, IP2, and IP3; 4, CA2; 5, UO1; 6, BO23; 7, A26S; 8, VS461 ${ }^{\mathrm{T}} ; 9$, DK8 and ECM1; 10, 19952; 11, 25015; 12, CA55 and CA128; 13, DN127: 14, UK; 15, VS116; 16, HO14 ${ }^{\mathrm{T}}$; 17, F63B, COW 611A, COW 611C, and O612; 18, NT29; 19, A19S; 20, Ip89; 21, VS102; 22, VSBP and P/Bi; 23, SIKA1 and SIKA2; 24, Poti B1, Poti B2, and Poti B3; 25, M3001; 26, 0M2007. The values on the upper right are absolute identity values (absolute numbers of residues), and the values on the lower left are percentages. The blank spaces indicate self-identity values of $100 \%$ (for 327 nucleotides and 108 amino acids).

be located on the chromosome rather than on mobile extrachromosomal DNA. Furthermore, genes obviously involved in lateral transfer or evolutionary convergence should be avoided. The usefulness of the $h b b$ gene in these types of studies compared with other Borrelia genes is discussed below.

Some of the most relevant Borrelia genes whose sequences have been studied are the genes coding for outer surface pro- teins $(\operatorname{osp} A, \operatorname{osp} B, \operatorname{osp} C$, and $\operatorname{osp} D)$, the gene encoding immunodominant protein $\mathrm{p} 83 / 100$, the major flagellin gene $f l a$, the genes for heat shock proteins HSP60 and HSP70, and the ribosomal DNA regions, such as $16 \mathrm{~S}$ rRNA and the $r f-r r l$ interspace $(13,19,26,32,33,35,39,41,46,47,53,54)$. Some of these genes, particularly the $o s p$ genes and the p83/100 gene, are essentially components of immunologically relevant borre- 
TABLE 2. Alignment of the amino acid sequences of the signature region characterizing the histone-like DNA-binding proteins of various organisms

\begin{tabular}{lll}
\hline \multicolumn{1}{c}{ Organism(s) } & \multicolumn{1}{c}{ Protein } & \multicolumn{1}{c}{ Signature sequence $^{a}$} \\
\hline Rhizobium leguminosarum & HRL18 & GFGSFSVSRREAS-KGRNPST \\
Rhizobium leguminosarum & HRL53 & GFGSFTVSHRAAT-KGRNPST \\
Rhizobium meliloti & HRM & GFGNFSVSREASK-GRRNPST \\
Escherichia coli & HU & GFGTFKVNHRAER-TGRNPQT \\
Salmonella typhimurium & HU & GFGTFKVNHRAER-TGRNPQT \\
Vibrio proteolyticus & HU & GFGTFKVNHRAAR-TGRNPKT \\
Pseudomonas aeruginosa & HU & GFGTFAVKERAAR-TGRNPQT \\
Anabaena sp. & HU & GFGSFESRERKAR-EGRNPKT \\
Cryptomonas (chloroplast) & HU & GFGSFEARERKAR-EGRNPRT \\
Clostridium pasteurianum & HU & GFGTFETRERAAR-EGRNPRT \\
Bacillus stearothermophilus & HU & GFGNFEVRERAAR-KGRNPQT \\
Bacillus subtilis & HU & GFGNEEVRERSAR-KGRNPQT \\
Thermus aquaticus & II & GFGTFEVRKRKAR-TGVKPGT \\
Escherichia coli & IHF-HIMD & GFGSFSLHYRAPR-TGRNPKT \\
Serratia marcescens & IHF-HIMD & GFGSFSLHYRAPR-VGRNPKT \\
Escherichia coli & IHF-HIMA & GFGNFDLRDKNQR-PGRNPKT \\
Serratia marcescens & IHF-HIMA & GFGNFDLRDKNQR-PGRNPKT \\
Salmonella typhimurium & IHF-HIMA & GFGNFGLRDKNQR-PGRNPKT \\
Rhodobacter capsulatus & IHF-HIMA & SFGTFSVRDKTSR-MGRNPKT \\
Thermoplasma acidophilum & HTA & GFGIFERRTQGPR-KARNPQT \\
Bacteriophage SPO1 & TF1 & GFLNIKPVARQAR-KGFNPQT \\
B. burgdorferi sensu lato & HBb & SFGTFEVRKRKGRLNARNPQT \\
19952 and DN127 & HBb & SFGTFEVRKRRGRLNARNPQT \\
25015 & HBb & SFGTFELRKRKGRQNARNPQT \\
B. parkeri and B. turicatae & HBb & SFGTFELRKRKGRLNARNPQT \\
\hline
\end{tabular}

${ }^{a}$ Positions 2, 19, and 21 are perfectly conserved. lial structures related to the host-pathogen interaction and, therefore, presumably are under specific and significant selective pressure from the host. Although knowledge of the diversity of these genes is crucial for vaccine development, their use in phylogenetic studies is less suitable. Furthermore, lateral transfer among members of the osp family seems to occur quite often. Evidence showing that recombinational events occur with $\operatorname{ssp} D$ and $\operatorname{ssp} C$ has been reported recently $(26,31,35,55)$. While intragenic recombination seems to be rare for $\operatorname{osp} A(15)$, this phenomenon has not been observed with the remaining $o s p$ genes. In contrast to the $o s p$ genes, the $h b b$ gene is encoded within the chromosome and does not seem to be subject to lateral transfer. In addition, in most reported studies, either a limited number of isolates or isolates that are not representative of the whole range of $B$. burgdorferi sensu lato species have been used in the sequence analysis. The advantage of this study is that we used a broad array of isolates (39 strains), including strains from a wide geographic area and different vector species and strains which are responsible for the complete spectrum of symptomatic manifestations of Lyme disease (erythema chronicum migrans, neurological and cardiac disorders, arthritis, acrodermatitis chronica atrophicans, and neuropathies of the central nervous system) (4).

In general, the variation in $h b b$ is significantly lower than the variation in the osp genes. The length of the $h b b$ gene is perfectly conserved ( $327 \mathrm{bp}$, with no gaps), while all other genomic regions described in other alignment studies are not. Moreover, the overall identities, as measured at the deduced amino acid level, of $74.4 \%$ for $\operatorname{osp} A$ (among 19 isolates of $B$. burgdorferi sensu lato), $60 \%$ for $o s p C$ (among 34 isolates of $B$. burgdorferi sensu lato), and $80 \%$ for $\operatorname{ospD}$ (among 15 isolates of B. burgdorferi sensu lato) are significantly lower than the values

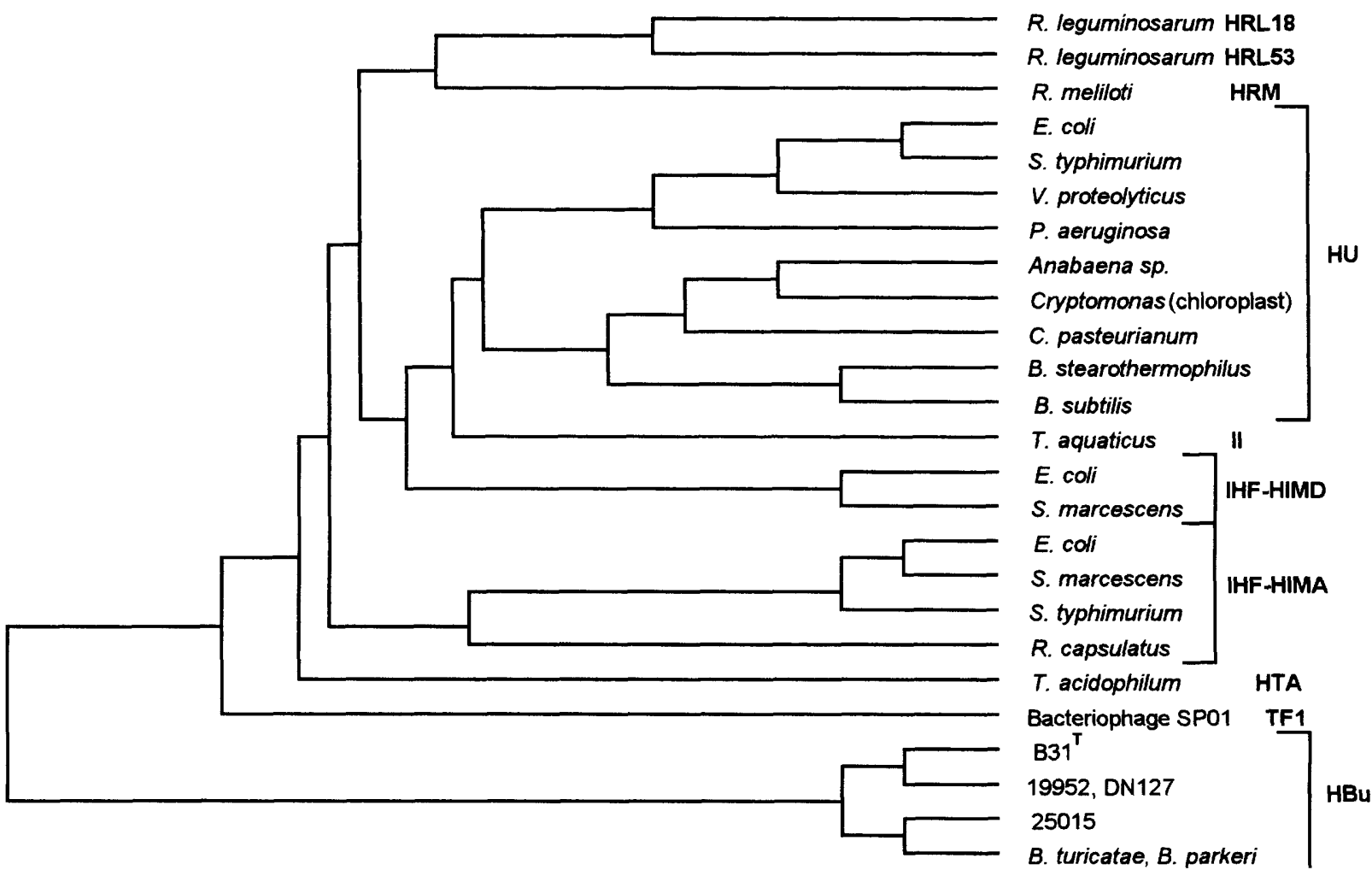

FIG. 4. Dendrogram generated with the amino acid sequences of the signature region characterizing the family of bacterial histone-like DNA-binding proteins from various organisms. It is predicted that this region forms the first half of the flexible DNA-binding arm. 
found for the $h b b$ gene among 37 isolates of $B$. burgdorferi sensu lato (more than 93\%). If non-Lyme disease spirochetes were considered, the identity dropped to $85 \%$.

Significance of this study. One might question whether this work was useful for any purpose other than fundamental research purposes. Besides providing new insights into the genetic structure of bacterial populations of the genus Borrelia, this study allowed us to design a specific and sensitive nested PCR for the detection of a wide spectrum of Borrelia strains, including all of the species of $B$. burgdorferi sensu lato, as well as $B$. parkeri and $B$. turicatae (50). This new PCR assay might have applications both in clinical diagnosis and in fundamental research, allowing workers to detect and phylogenetically characterize strains without having to perform fastidious and often unsuccessful cultivation procedures.

Conclusions. We believe that the sequence of the $h b b$ gene provides valuable information for phylogenetic studies in the genus Borrelia. The sequence analysis of this gene confirmed the subdivision of $B$. burgdorferi sensu lato into five species $(B$. burgdorferi sensu stricto, B. garinii, B. afzelii, B. japonica, and " $B$. andersonii") and at least four genomic groups (groups PotiB1, CA2, DN127, and VS116). Although our data originated from a single gene locus, they are consistent with information acquired by methods involving the whole genome, such as MLEE and DNA-DNA hybridization. In conclusion, our original hypothesis that histone-like proteins might be suitable targets for molecular phylogenetic investigations in bacterial species was confirmed in this work. The use of sequence analysis of genes encoding such proteins might be adequate for the study of the genetic structure of other bacterial populations as well.

\section{ACKNOWLEDGMENTS}

We are especially grateful to Kit Tilly, National Institutes of Health, Hamilton, Mont., for kindly providing the original sequence of the $h b b$ gene of strain $\mathrm{B} 31^{\mathrm{T}}$ prior to publication. We thank R. T. Marconi, B. Wilske, and K. Tilly for helpful comments and valuable discussions and J. M. Musser and M. Chandler for revising the manuscript.

This work was supported by grants 31-36566.92 and 31-45914.95 from the Swiss National Foundation for Scientific Research to J.-C.P.

\section{REFERENCES}

1. Anthonissen, F. M., M. De Kesel, P. P. Hoet, and G. H. Bigaignon. 1994. Evidence for the involvement of different genospecies of Borrelia in the clinical outcome of Lyme disease in Belgium. Res. Microbiol. 145:327-331.

2. Assous, M. V., D. Postic, G. Paul, P. Névot, and G. Baranton. 1993. Western blot analysis of sera from Lyme borreliosis patients according to the genomic species of the Borrelia strains used as antigens. Eur. J. Clin. Microbiol. Infect. Dis. 12:261-268.

3. Assous, M. V., D. Postic, G. Paul, P. Névot, and G. Baranton. 1994. Individualisation of two genomic groups among American Borrelia burgdorferi sensu lato strains. FEMS Microbiol. Lett. 121:93-98.

4. Balmelli, T., and J.-C. Piffaretti. 1995. Association between different clinical manifestations of Lyme disease and different species of Borrelia burgdorferi sensu lato. Res. Microbiol. 146:329-340.

5. Balmelli, T., and J.-C. Piffaretti. 1996. Analysis of the genetic polymorphism of Borrelia burgdorferi sensu lato by multilocus enzyme electrophoresis. Int. J. Syst. Bacteriol. 46:167-172

6. Baranton, G., D. Postic, I. Saint Girons, P. Boerlin, J.-C. Piffaretti, M. Assous, and P. A. D. Grimont. 1992. Delineation of Borrelia burgdorferi sensu stricto, Borretia garinii sp. nov., and group VS 461 associated with Lyme borreliosis. Int. J. Syst. Bacteriol. 42:378-383.

7. Benachenhou-Lahfa, N., B. Labedan, and P. Forterre. 1994. PCR-mediated cloning and sequencing of the gene encoding glutamate dehydrogenase from the archaeon Sulfolobus shibatae: identification of putative amino-acid signatures for extremophilic adaptation. Gene 140:17-24.

8. Boerlin, P., O. Péter, A. G. Bretz, D. Postic, G. Baranton, and J.-C. Piffaretti. 1992. Population genetics of Borrelia burgdorferi isolates by multilocus enzyme electrophoresis. Infect. Immun. 60:1677-1683.

9. Boerlin, P., J. Rocourt, F. Grimont, P. A. D. Grimont, C. Jacquet, and J.-C. Piffaretti. 1992. Listeria ivanovii subsp. londoniensis subsp. nov. Int. J. Syst. Bacteriol. 42:69-73.
10. Brown, J. R., Y. Masuchi, F. T. Robb, and W. F. Doolittle. 1994. Evolutionary relationships of bacterial and archaeal glutamine synthetase genes. J. Mol. Evol, 38:566-576.

11. Burgdorfer, W., A. G. Barbour, S. F. Hayes, J. L. Nenach, E. Gruwldt, and J. P. Davies. 1982. Lyme disease a tick borne spirochetosis? Science 216: 1317-1319.

12. Canica, M. M., F. Nato, L. du Merle, J. C. Mazie, G. Baranton, and D. Postic. 1993. Monoclonal antibodies for identification of Borrelia afzelii $\mathrm{sp}$. nov. associated with late cutaneous manifestations of Lyme borreliosis. Scand. J. Infect. Dis. 25:441-448.

13. Caporale, D. A., and T. D. Kocher. 1994. Sequence variation in the outersurface-protein genes of Borrelia burgdorferi. Mol. Biol. Evol. 11:51-64.

14. Drlica, K., and J. Rouviere-Yaniv. 1987. Histone-like proteins of bacteria. Microbiol. Rev. 51:301-319.

15. Dykhuizen, E. D., D. S. Polin, J. J. Dunn, B. Wilske, V. Preac-Mursic, R. J. Dattwyler, and B. J. Luft. 1993. Borrelia burgdorferi is clonal: implications for taxonomy and vaccine development. Proc. Natl. Acad. Sci. USA 90:1016310167.

16. Felsenstein, J. 1993. PHYLIP (phylogeny inference package), version 3.5c. Department of Genetics, University of Washington, Seattle.

17. Friedman, D. I. 1988. Integration host factor: a protein for all reasons. Cell 55:545-554.

18. Fukunaga, M., and Y. Koreki. 1995. The flagellin gene of Borrelia miyamotoi sp. nov. and its phylogenetic relationship among Borrelia species. FEMS Microbiol. Lett. 34:255-258.

19. Gassmann, G. S., E. Jacobs, R. Deutzmann, and U. B. Gobel. 1991. Analysis of the Borrelia burgdorferi GeHo fla gene and antigenic characterization of its gene product. J. Bacteriol. 173:1452-1459.

20. Gupta, R. S. 1995. Evolution of the chaperonin families (Hsp60, Hsp10 and Tcp-1) of proteins and the origin of eukaryotic cells. Mol. Microbiol. 15:1-11.

21. Haluzi, H., D. Goitein, S. Koby, I. Mendelson, D. Teff, G. Mengeritsky, H. Giladi, and A. B. Oppenheim. 1991. Genes coding for integration host factor are conserved in gram-negative bacteria. J. Bacteriol. 173:6297-6299.

22. Higgins, D. G., A. J. Bleasby, and R. Fuchs. 1991. CLUSTAL V: improved software for multiple sequence alignment. CABIOS 8:189-191.

23. Higgins, D. G., and P. M. Sharp. 1988. Fast and sensitive multiple sequence alignments on a microcomputer. CABIOS 5:151-153.

24. Hyde, F. W., and R. C. Johnson. 1984. Genetic relationship of Lyme disease spirochetes to Borrelia, Treponema, and Leptospira spp. J. Clin. Microbiol. 20:151-154

25. Jauris, S., K. P. Rücknagel, W. H. Schwarz, P. Kratzsch, K. Bronnenmeier, and W. L. Staudenbauer. 1990. Sequence analysis of the Clostridium stercorarium celZ gene encoding a thermoactive cellulase (Avicelase I): identification of a catalytic and cellulose-binding domains. Mol. Gen. Genet. 223: $258-267$.

26. Jauris-Heipke, S., G. Liegl, V. Preac-Mursic, D. Rössler, E. Schwab, E. Soutschek, G. Will, and B. Wilske. 1995. Molecular analysis of genes encoding outer surface protein $\mathrm{C}$ (OspC) of Borrelia burgdorferi sensu lato: relationship to $\operatorname{sp} A$ genotype and evidence of lateral gene exchange of $\operatorname{ssp} C$. J. Clin. Microbiol. 33:1860-1866.

27. Karlin, S., G. M. Weinstock, and V. Brendel. 1995. Bacterial classifications derived from RecA protein sequence comparisons. J. Bacteriol. 177:68816893 .

28. Kawabata, H., T. Masuzawa, and Y. Yanagihara. 1993. Genomic analysis of Borrelia japonica sp. nov. isolated from Ixodes ovatus in Japan. Microbiol. Immunol. 37:843-848.

29. Kumada, Y., D. R. Benson, D. Hillemann, T. J. Hosted, D. A. Rochefor, C. J. Thompson, W. Wohlleben, and Y. Tateno. 1993. Evolution of the glutamine synthetase gene, one of the oldest existing and functioning genes. Proc. Natl. Acad. Sci. USA 90:3009-3013.

30. Livesley, M. A., I. P. Thompson, L. Gern, and P. A. Nuttall. 1993. Analysis of intra-specific variation in the fatty acid profiles of Borrelia burgdorferi. J. Gen. Microbiol. 139:2197-2201.

31. Livey, I., C. P. Gibbs, R. Schuster, and F. Dorner. 1995. Evidence for lateral transfer and recombination in OspC variation in Lyme disease Borrelia. Mol. Microbiol. 18:257-269.

32. Marconi, R. T., and C. F. Garon. 1992. Identification of a third genomic group of Borrelia burgdorferi through signature nucleotide analysis and $16 \mathrm{~S}$ rRNA sequence determination. J. Gen. Microbiol. 138:533-536.

33. Marconi, R. T., and C. F. Garon. 1992. Phylogenetic analysis of the genus Borrelia: a comparison of North American and European isolates of Borrelia burgdorferi. J. Bacteriol. 174:241-244.

34. Marconi, R. T., D. Liveris, and I. Schwartz. 1995. Identification of novel insertion elements, restriction fragment length polymorphism patterns, and discontinuous 23S rRNA in Lyme disease spirochetes: phylogenetic analyses of rRNA genes and their intergenic spacers in Borrelia japonica sp. nov. and genomic group 21038 (Borrelia andersonii sp. nov.) isolates. J. Clin. Microbiol. 33:2427-2434.

35. Marconi, R. T., D. S. Samuels, R. K. Landry, and C. F. Garon. 1994. Analysis of the distribution and molecular heterogeneity of the $\operatorname{ssp} D$ gene among the Lyme disease spirochetes: evidence for lateral gene exchange. J. Bacteriol. 176: $4572-4582$. 
36. Mendelson, I., M. Gottesman, and A. B. Oppenheim. 1991. HU and integration host factor function as auxiliary proteins in cleavage of phage lambda cohesive ends by terminase. J. Bacteriol. 173:1670-1676.

37. Noppa, L., N. Burman, A. Sadziene, A. G. Barbour, and S. Bergström. 1995. Expression of the flagellin gene in Borrelia is controlled by an alternative $\sigma$ factor. Microbiology (Washington, D.C.) 141:85-93.

38. Oberto, J., K. Drlica, and J. Rouvière-Yaniv. 1994. Histones, HGM, HU, IHF: même combat. Biochimie 76:901-908.

39. Postic, D., M. V. Assous, P. A. D. Grimont, and G. Baranton. 1994. Diversity of Borrelia burgdorferi sensu lato evidenced by restriction fragment length polymorphism of rrf $5 \mathrm{~S}-\mathrm{rrl} 23 \mathrm{~S}$ intergenic amplicons. Int. J. Syst. Bacteriol. 44:743-752.

40. Rivera, M. C., and J. A. Lake. 1992. Evidence that eukaryotes and eocyte prokaryotes are immediate relatives. Science 257:74-76.

41. Rössler, D., H. Eiffert, S. Jauris-Heipke, G. Lehnert, V. Preac-Mursic, J. Teepe, T. Schlott, E. Soutschek, and B. Wilske. 1995. Molecular and immunological characterization of the $\mathrm{p} 83 / 100$ protein of various Borrelia burgdorferi sensu lato strains. Med. Microbiol. Immunol. 184:23-32.

42. Schmid, M. B. 1990. More than just histone-like proteins. Cell 63:451-453.

43. Selander, R. K., D. A. Caugant, H. Ochman, J. M. Musser, M. N. Gilmour, and T. S. Whittam. 1986. Methods of multilocus enzyme electrophoresis for bacterial population genetics and systematics. Appl. Environ. Microbiol 51:873-884.

44. Sonnhammer, E. L. L., and D. Kahn. 1994. The modular arrangement of proteins as inferred from analysis of homology. Protein Sci. 3:482-492.

45. Tanaka, I., K. Appelt, J. Dijk, S. W. White, and K. S. Wilson. 1984. resolution structure of a protein with histone-like properties in prokaryotes. Nature 310:376-381.

46. Theisen, M., M. Borre, M. J. Matheisen, B. Mikkelsen, A.-M. Lebech, and K. Hansen. 1995. Evolution of the Borrelia burgdorferi outer surface protein OspC. J. Bacteriol. 177:3036-3044.

47. Theisen, M., B. Frederiksen, A.-M. Lebech, J. Vuust, and K. Hansen. 1993 Polymorphism in $o s p C$ of Borrelia burgdorferi and immunoreactivity of $\mathrm{OspC}$ protein as diagnostic antigen. J. Clin. Microbiol. 31:2570-2576.

48. Tiboni, O., P. Cammarano, and A. M. Sanangelantoni. 1993. Cloning and sequencing of the gene encoding glutamine synthetase I from the archeum Pyrococcus woesi: anomalous phylogenies inferred from analysis of archeal and bacterial glutamine synthetase I sequences. J. Bacteriol. 175:22712277.

49. Tilly, K., J. Fuhrman, J. Campbell, and D. S. Samuels. 1996. Isolation of Borrelia burgdorferi genes encoding homologs of DNA-binding protein HU and ribosomal protein S20. Microbiology 142:2471-2479.

50. Valsangiacomo, C., T. Balmelli, and J.-C. Piffaretti. A nested polymerase chain reaction for the detection of Borrelia burgdorferi sensu lato based on the $h b b$ gene. FEMS Microbiol. Lett., in press.

51. van Dam, A. J., H. Kuiper, K. Vos, A. Widjojkusumo, B. M. de Jongh, L. Spanjaard, A. C. P. Ramselaar, D. M. Kramer, and J. Dankert. 1993. Different genospecies of Borrelia burgdorferi are associated with distinct clinical manifestation of Lyme disease. Clin. Infect. Dis. 17:708-717.

52. Viale, A. M., and A. K. Arakaki. 1994. The chaperone connection to the origins of the eukaryotic organelles. FEBS Lett. 341:146-151.

53. Wallich, R., C. Helmes, U. E. Schaible, Y. Lobet, S. E. Moter, M. D. Kramer, and M. M. Simon. 1992. Evaluation of genetic divergence among Borrelia burgdorferi isolates by use of OspA, $f l a$, HSP60, and HSP70 gene probes. Infect. Immun. 60:4856-4866.

54. Wil, G., S. Jauris-Heipke, E. Schwab, U. Busch, D. Rössler, D. Soutschek, B. Wilske, and V. Preac-Mursic. 1995. Sequence analysis of $\operatorname{csp} A$ genes shows homogeneity within Borrelia burgdorfer sensu stricto and Borrelia afzelit strains but reveals major subgroups within the Borrelia garinii species. Med. Microbiol. Immunol. 184:73-80.

55. Wilske, B., S. Jauris-Heipke, R. Lobentanzer, I. Pradel, V. Preac-Mursic, D. Rössler, E. Soutschek, and R. C. Johnson. 1995. Phenotypic analysis of outer surface protein $\mathrm{C}(\operatorname{osp} C)$ of Borrelia burgdorferi sensu lato by monoclonal antibodies: relationship to genospecies and ospA serotype. J. Clin. Microbiol. 33:103-109.

56. Woese, C. R. 1987. Bacterial evolution. Microbiol. Rev. 51:221-271. 